\title{
Penguatan Kapasitas Kelembagaan Asisten Deputi Pengaduan Masyarakat Kementerian Sekretariat Negara dalam Penanganan Pengaduan Masyarakat kepada Presiden RI
}

\author{
Metia Pratiwi ${ }^{1}$, Roy V. Salomo ${ }^{2}$ \\ ${ }^{1}$ Fakultas Ilmu Administrasi, Universitas Indonesia, Indonesia \\ ${ }^{2}$ Fakultas Ilmu Administrasi, Universitas Indonesia, Indonesia
}

\section{INFO ARTIKEL}

Riwayat Artikel:

Diterima: 10-04-2020

Disetujui: 27-04-2020

\section{Kata Kunci: \\ 1. Kapasitas Kelembagaan \\ 2. Sumber Daya \\ 3. Manajemen \\ 4. Penanganan Pengaduan Masyarakat}

Keyword:

1. Capacity Building

2. Resources

3. Management

4. Public Complaint Handling

\section{ABSTRAK}

Abstrak: Kebebasan masyarakat dalam menyampaikan pengaduan tidak terkecuali kepada Presiden RI. Jumlah pengaduan masyarakat kepada Presiden RI menunjukan tren kenaikan setiap tahunnya, dengan jumlah signifikan di era Pemerintahan Joko Widodo. Seiring dengan tingginya tuntutan masyarakat terhadap penyelesaian masalah di lembaga kepresidenan dan kecepatan dinamika lingkungan, maka penguatan kapasitas kelembagaan Kementerian Sekretariat Negara sangatlah vital. Namun dalam praktiknya penyelenggaraan penanganan pengaduan masih jauh dari harapan, yakni banyak pengaduan yang belum mendapatkan penyelesaian dari instansi terkait, belum terbentuknya sinergisitas penanganan pengaduan, dan mekanisme kerja yang masih konvensional.

Penelitian ini bertujuan untuk menganalisis kapasitas kelembagaan yang perlu diperkuat dalam menyelenggarakan penanganan pengaduan masyarakat kepada Presiden RI. Peneliti menggunakan pendekatan post positivisme dengan metode penelitian kualitatif melalui wawancara mendalam dan studi dokumentasi.

Hasil penelitian menunjukan bahwa perlu penguatan kapasitas kemampuan SDM dalam menjalankan tugas dan fungsi public complaint handling melalui pendidikan dan pelatihan, pengembangan dan pemanfaatan sistem teknologi dalam mengelola dan menganalisis data pengaduan serta memperlancar proses bisnis yang masih terkendala, proses evaluasi kinerja penanganan secara menyeluruh, pembentukan payung hukum sebagai pedoman penanganan pengaduan masyarakat kepada Presiden RI, dukungan dari pimpinan, dan kerja sama secara kelembagaan antar mitra pengelola pengaduan dalam menangani pengaduan masyarakat kepada Presiden RI.

Abstract: Freedom to public complaint is also addresed to President of Republic of Indonesia. The number of public complaint to the President has tended to increase every year, with a significant increase in the era of Joko Widodo. Along with the high public demand towards solving problems and the speed with environmental, strengthening the institutional capacity of Ministry of State Secretariat is a vital. However, handling complaints is still far from what is expected, namely that there are many complaints that have not yet been resolved, complaint handling has not been synergistic, and most of handling mechanisms are still conventional. This study aims to analyze the institutional capacity that needs to be strengthened by the Deputy Assistant for Public Complaint in organizing the handling of public complaints. Researcher used the post positivism approach with qualitative research method through indepth interviews and documentation studies. The result showed that the need to strengthen capacity of human resource capabilities in carrying out public complaint handling tasks through 
238 JIAP | Jurnal IImu Administrasi Publik | Vol. 8, No. 1, Bulan Maret Tahun 2020 hal 237-255

education and training, development and utilization of technology systems that support the needs of organization in managing and analyzing data, process of evaluating the overall handling of performance, the need for establishment of guidline for public complaint handling to the President, support from the leadership, and strengthening cooperation between institutions. 


\section{Latar Belakang}

Pengaduan masyarakat telah menjadi perhatian banyak negara yang memiliki komitmen dalam mewujudkan peningkatan pelayanan publik. Kemunculan pengaduan biasanya disebabkan oleh ketidakpuasan masyarakat atas perlakuan aparat dalam menjalankan kewajibannya. Michael Gorton, dkk mendefinisikan pengaduan sebagai " $a$ vital form of consumer feedback that provides unique and valuable information to an organization concerned with quality improvement" (Department of Health \& Human Services, 2012). Pada sektor publik, pengaduan masyarakat dapat menjadi salah satu isu reformasi administrasi dalam rangka mencegah patologi birokrasi. Oleh karena itu pengaduan dapat dikatakan sebagai elemen penting bagi suatu organisasi untuk memperbaiki dan meningkatkan kualitas layanannya.

Di Indonesia, reformasi telah membuka ruang dan kesempatan yang luas bagi masyarakat untuk menyampaikan pengaduan. Perubahan paradigma aparat juga dituntut dalam memahami konsep pengaduan masyarakat itu sendiri. Pengaduan masyarakat diartikan sebagai bentuk partisipasi masyarakat dalam memberikan masukan yang bersifat konstruktif dalam rangka memperbaiki kinerja pemerintah, baik dalam bentuk keluhan, pendapat, kritikan, dan apresiasi. Apalagi dengan adanya kebijakan desentralisasi, maka perubahan manajemen pelayanan yang lebih efektif dan efisien adalah salah satu yang dinanti. Dalam Undang-Undang Nomor 25 Tahun 2009 tentang Pelayanan Publik Pasal 18, disebutkan bahwa masyarakat berhak untuk mengadukan pelaksana layanan yang tidak menjalankan Standard Operating Procedures (SOP) kepada penyelenggara dan memperoleh tanggapan atas pengaduan tersebut. Adanya kebijakan tersebut mengamanatkan kewajiban Pemerintah dalam menyelenggarakan penanganan pengaduan masyarakat. Instansi pemerintah harus menyediakan sistem yang jelas mulai dari penerimaan sampai pada penyelesaian guna mengelola pengaduan secara komprehensif. (Brewer, 2007) menyampaikan bahwa hasil penanganan tersebut harus disampaikan secara jelas, sekalipun tidak dapat ditindaklanjuti berdasarkan aturan yang berlaku.

Penanganan pengaduan masyarakat sebetulnya bukan merupakan isu baru. Sejumlah kebijakan telah mengamanatkan instansi pengelola pengaduan untuk menangani pengaduan, meliputi Peraturan Presiden Nomor 76 Tahun 2013 tentang Pengelolaan Pengaduan Pelayanan Publik, Peraturan Menteri Pendayagunaan Aparatur Negara dan Reformasi Birokrasi Nomor 24 Tahun 2014 tentang Pedoman Penyelenggaraan Pengelolaan Pengaduan Pelayanan Publik secara Nasional, dsb. Bahkan lebih tegas lagi, pada masa Pemerintahan Joko Widodo Jilid I, dikenal adanya Nawa Cita, yang salah satu butirnya mendorong pentingnya kehadiran peran Negara di tengah permasalahan masyarakat, yaitu "menghadirkan kembali Negara untuk melindungi segenap bangsa dan memberikan rasa aman pada seluruh warga Negara serta membuat Pemerintah tidak absen dengan tata kelola pemerintahan yang bersih, efektif, transparan, akuntabel, dan demokratis". Namun demikian, hadirnya berbagai kebijakan belum cukup untuk mewujudkan penyelenggaraan penanganan pengaduan yang optimal. Layanan pengaduan oleh instansi pemerintah terkesan hanya upaya formalitas dan belum menjadi agenda prioritas untuk mewujudkan partisipasi dan keterbukaan informasi publik. Menurut sebagian peneliti, streotip yang kurang baik, seperti terlalu birokratis, lamban, dsb seolah telah melekat pada pengelolaan pengaduan sektor publik (Heracleous \& Johnston, 2009). Kondisi tersebut sungguh sangat jauh mencerminkan konsep pelayanan publik yang diamanatkan undang-undang.

Pengaduan masyarakat sejatinya tidak dapat dibatasi/dihalangi, sekalipun ditujukan kepada Presiden RI sebagai Kepala Negara dan Pemerintahan. Sejak tahun 2005, Presiden Soesilo Bambang Yudhoyono 
membuka ruang bagi masyarakat untuk menyampaikan aduan lewat berbagai media, seperti surat, SMS, dan media sosial. Permasalahan yang diadukan sangat beragam seperti hukum, agraria, pelayanan publik, ketenagakerjaan, aparatur, penyalahgunaan kewenangan, korupsi, dsb, dengan lokus permasalahan berada di instansi Pusat maupun daerah di seluruh wilayah Indonesia. Upaya ini berhasil mencuri perhatian publik yang ditunjukan dengan banyaknya surat pengaduan kepada Presiden RI melalui Kementerian Sekretariat Negara. Dalam rangka mewujudkan penanganan pengaduan yang lebih komprehensif integral, maka pada tahun 2005 dibentuk unit kerja Biro Pengaduan Masyarakat atau saat ini bernama Asisten Deputi Pengaduan Masyarakat.

Asisten Deputi Pengaduan Masyarakat bertugas dalam menyelenggarakan penanganan pengaduan masyarakat kepada Presiden RI sebagaimana Peraturan Menteri Sekretaris Nomor 3 Tahun 2015 tentang Organisasi dan Tata Kerja Kementerian Sekretariat Negara. Fungsi unit kerja tersebut ialah melakukan analisis dan koordinasi dalam rangka mendorong penyelesaian pengaduan masyarakat oleh instansi teknis yang berwenang. Fungsi ini sejalan dengan tugas Kementerian Sekretariat Negara sebagaimana Peraturan Presiden 24 Tahun 2005 tentang Kementerian Sekretariat Negara yaitu melakukan penajaman, koordinasi, dan sinkronisasi.

Asisten Deputi Pengaduan Masyarakat menjalankan berbagai tahapan dalam penanganan pengaduan, yaitu mulai dari penerimaan sampai pada penyampaian hasil penanganan baik kepada masyarakat maupun mitra Kementerian Sekretariat Negara meliputi DPR, instansi pusat dan daerah, dsb. Hasil penyelesaian pengaduan ini juga selanjutnya akan menjadi bahan laporan Kementerian Sekretariat Negara kepada Presiden RI.

Sejak tahun 2005, tren jumlah pengaduan masyarakat kepada Presiden cenderung terus meningkat. Sampai pada tahun 2019, jumlah surat pengaduan kepada Presiden RI mencapai sebanyak 131.583 surat, dengan kenaikan jumlah secara signifikan mulai terjadi pada tahun 2015 di era Presiden Joko Widodo. Jika dibandingkan dengan era Presiden Soesilo Bambang Yudhoyono, jumlah pengaduan di era Presiden Joko Widodo mencapai 2 kali lipatnya. Berikut ditunjukan pada grafik 1 di bawah ini:

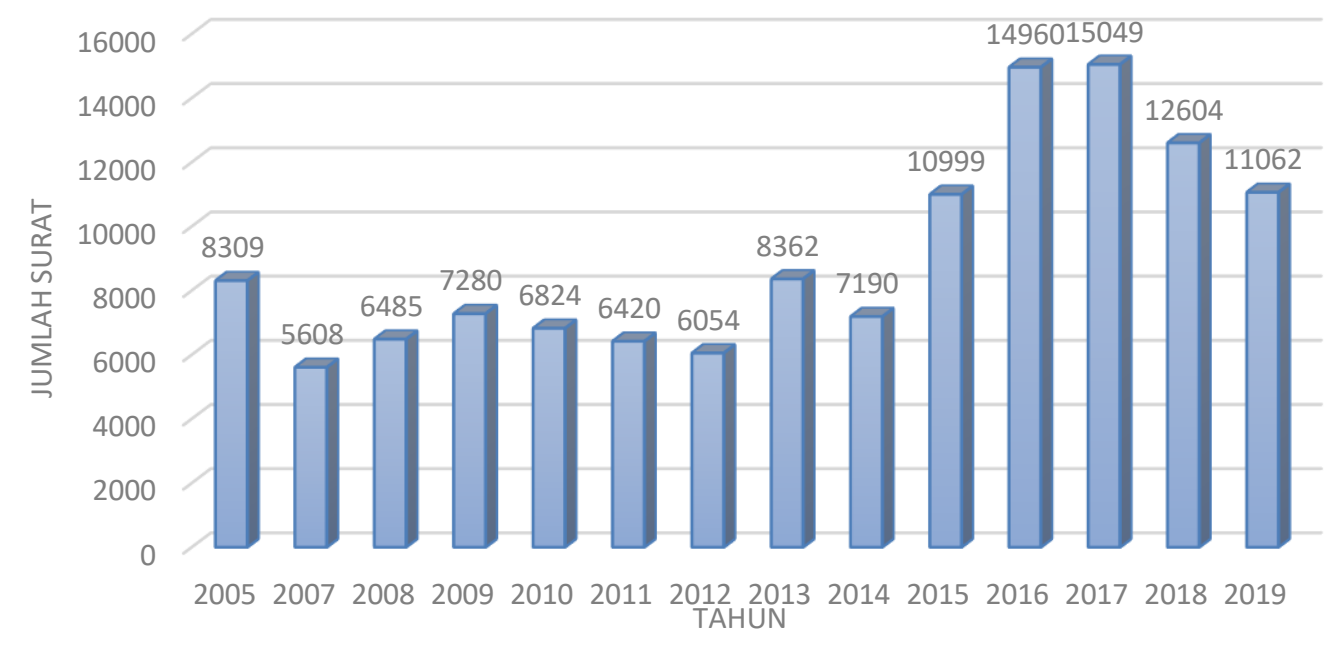

Grafik 1 Jumlah Surat Pengaduan Masyarakat kepada Presiden RI

Sumber: Data Olah Pribadi, 2019

Meskipun saluran pengaduan berbasis IT secara nasional telah dikembangkan Kementerian Pendayagunaan Aparatur
Negara dan Reformasi Birokrasi melalui sistem LAPOR!, nyatanya jumlah pengaduan kepada Presiden RI yang 
disampaikan melalui surat masih jauh melampaui. Banyaknya jumlah tersebut dipahami karena keterbatasan akses teknologi pada masyarakat, implikasi dari keterbukaan zaman, dan figur kesederhanaan dan merakyat yang melekat pada kepemimpinan Presiden Joko Widodo sehingga mempengaruhi besarnya harapan masyarakat terhadap penyelesaian di lembaga kepresidenan. Kondisi ini menjadi suatu tantangan dan dilematis bagi Kementerian Sekretariat Negara. Kementerian Sekretariat Negara tentu tidak memiliki kewenangan secara teknis untuk menyelesaikan pengaduan, namun di sisi lain, pengaduan kepada Presiden RI harus mendapatkan perhatian.

Kementerian Sekretariat Negara menjalankan peran yang tak kalah penting yaitu sebagai fungsi koordinatif yang dinilai memiliki peran strategis sebagai "mata dan telinga Presiden" sehingga harapannya kapasitas kelembagaan harus mencerminkan fungsi tersebut. Akan tetapi setiap organisasi tentu menghadapi kendala dan permasalahan.

Berdasarkan Laporan Akuntabilitas Asisten Deputi Pengaduan Masyarakat pada Tahun 2016 s.d. 2019, kendala yang dihadapi unit kerja tersebut setiap tahunnya ialah terkait hubungan kerja sama antar instansi pengelola pengaduan yang memiliki kewenangan dalam penyelesaian masalah yang paling banyak diadukan, misalnya dengan kepolisian terkait masalah hukum, Kementerian Agraria dan Tata Ruang/BPN serta instansi vertikal di bawahnya terkait masalah agraria, dan sejumlah Pemerintah provinsi/kabupaten/kota terkait dengan permasalahan pemerintahan daerah, pelayanan publik, dll. Namun demikian, hubungan tersebut belum menunjukan suatu kerja sama yang terkelola dengan baik.

Berdasarkan Laporan Kinerja Asisten Deputi Pengaduan Masyarakat Tahun 2016 s.d. 2018, perbandingan antara jumlah pengaduan yang ditindaklanjuti Kementerian Sekretariat Negara kepada instansi terkait dengan jumlah pengaduan yang telah mendapatkan penyelesaian, yakni sekitar 50\%. Berbagai faktor penyebab hal tersebut di antaranya: 1. Belum ditindaklanjuti oleh instansi terkait, 2. Substansi pengaduan yang membutuhkan waktu penyelesaian lebih lama, 3. Keterbatasan Asisten Deputi Pengaduan Masyarakat untuk memonitor perkembangan setiap penanganan pengaduan, dsb. Berikut ditunjukan pada grafik 2 mengenai perbandingan jumlah pengaduan yang ditindaklanjuti Kementerian Sekretariat Negara dengan jumlah pengaduan yang telah mendapatkan penyelesaian oleh instansi terkait:

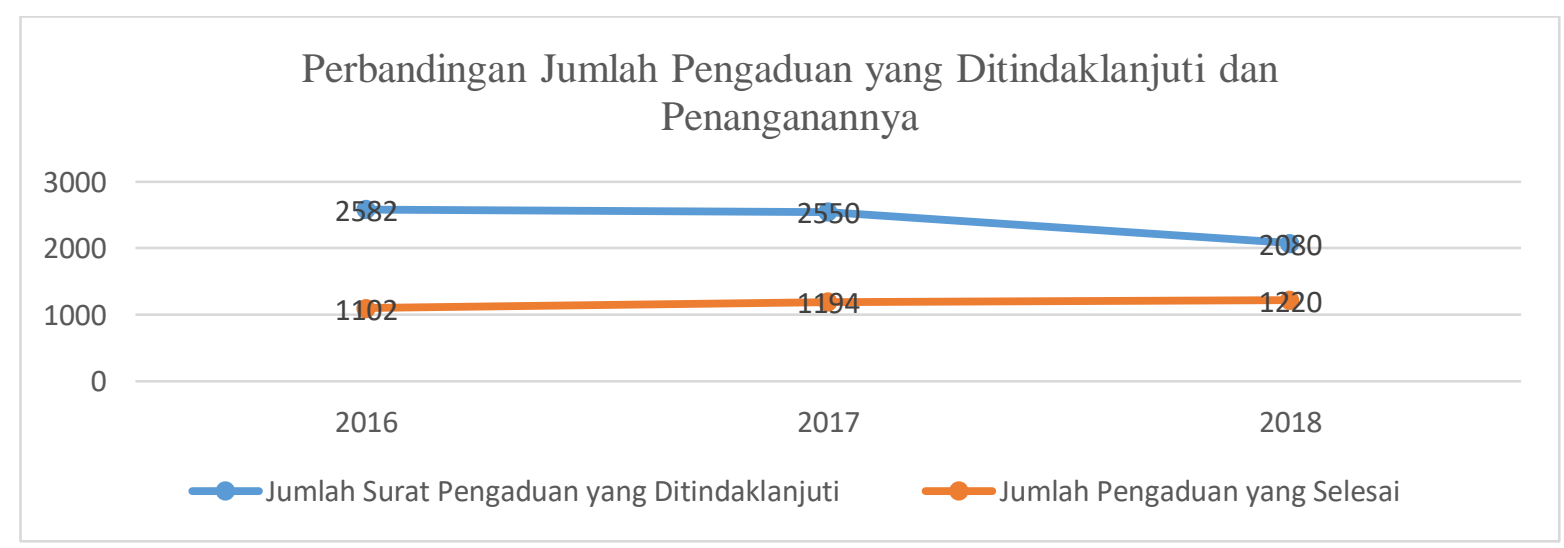

Grafik 2 Perbandingan Jumlah Pengaduan yang Ditindalanjuti dan Penanganannya Sumber: Data Olah Pribadi, 2019

Grafik 2 tersebut juga sesungguhnya menunjukan bahwa setiap tahunnya terdapat pengaduan yang belum terselesaikan dan menambah daftar tumpukan pengaduan yang harus didorong penyelesaiannya oleh Kementerian Sekretariat Negara. Tentu 
kondisi tersebut tidaklah mudah dihadapi oleh Kementerian Sekretariat Negara. Tekanan publik yang sangat besar menuntut peran dan kapasitas Kementerian Sekretariat Negara sebagai lembaga kepresidenan dalam menangani pengaduan. Selama ini kekecewaan publik tertuang dalam bentuk protes ke kantor Kementerian Sekretariat Negara, bahkan diluapkan dalam bentuk demonstrasi.

Menurut Indraswari (2017), pengembangan kapasitas pada Asisten Deputi Pengaduan Masyarakat dibutuhkan pada aspek kuantitas dan kualitas SDM, peremajaan teknologi, dan dukungan anggaran. Seiring dengan perkembangannya, aspek-aspek tersebut telah mengalami perkembangan seperti kuantitas SDM telah memadai, pemanfaatan teknologi yang terintegrasi dengan Sistem LAPOR!, dan melakukan monitoring penanganan pengaduan dengan cara tinjau lapangan. Namun demikian, penanganan pengaduan masyarakat masih menghadapi sejumlah kendala seperti tata kelola jejaring dengan instansi terkait yang belum optimal sehingga belum menciptakan satu kesatuan sistem penanganan pengaduan masyarakat khusus kepada Presiden RI, belum kuatnya komitmen instansi terkait dalam menangani pengaduan masyarakat kepada Presiden, dan terjadi tumpang tindih penanganan pengaduan di berbagai instansi.

Menurut Asisten Deputi Pengaduan Masyarakat, koordinasi dalam birokrasi saat ini masih menjadi barang mahal sehingga butuh peran siapapun yang menjadi pendorong lancarnya birokrasi (Menpan.go.id, 2018). Selain itu, mekanisme cara kerja pengaduan masyarakat juga perlu ditingkatkan melalui pembaharuan/inovasi agar dapat menyesuaikan dengan kecepatan dinamika lingkungan. Hal ini sesuai dengan arahan Menteri Sekretaris Negara, bahwa Kementerian Sekretariat Negara harus menjadi role model bagi kementerian lain dan berperan seperti layaknya "menara pengawas" yang mengatur banyak pilot dalam pemerintah. Maka demikian, perubahan organisasi sangat dibutuhkan untuk menyesuaikan dinamika masyarakat yang sangat cepat dan kompleks. Begitupula dalam penanganan pengaduan masyarakat, kebutuhan untuk melakukan penguatan kapasitas kelembagaan dalam penanganan pengaduan sangat diperlukan. Peran Asisten Deputi Pengaduan Masyarakat sebagai salah satu unit kerja di lembaga kepresidenan diharapkan dapat mencerminkan kapasitas yang kuat dan strategis.

Kapasitas kelembagaan ini merujuk pada prosedur dan mekanisme kerja, hubungan/jejaring antar organisasi, pembuatan keputusan, dsb. Kapasitas menunjukan kekuasaan atau kemampuan untuk melakukan beberapa hal tertentu (Frymier, 1987). Penguatan kapasitas pada Asisten Deputi Pengaduan Masyarakat ini dibutuhkan tidak hanya semata-mata faktor tingginya tuntutan kinerja, melainkan perlunya upaya-upaya baru dalam menghadapi pergeseran paradigma administrasi.

Dalam konteks penanganan pengaduan masyarakat, terdapat sejumlah faktor yang mempengaruhi keberhasilan proses penyelenggaraan tersebut meliputi dukungan pimpinan, dukungan sumber daya manusia, dan dukungan sarana dan prasarana (Menpan, 2016). Hal ini sejalan dengan pernyataan Horton, et al (Horton et al., n.d.) bahwa penguatan kapasitas yang seringkali dilakukan oleh organisasiorganisasi di negara berkembang hanya pada fisik dan keuangan, sedangkan aspek kapasitas yang paling penting seringkali luput dari perhatian, yaitu aspek kapasitas manajemen. Berdasarkan uraian pemikiran Horton, et.al tersebut peneliti melihat adanya gejala-gejala peneliti yang diuraikan pada latar belakang yang dapat dianalisis melalui teori Horton, et.al Oleh karena itu, tujuan penelitian ini ialah untuk menganalisis kapasitas kelembagaan yang perlu diperkuat oleh Asisten Deputi Pengaduan Masyarakat Kementerian Sekretariat Negara dalam menyelenggarakan penanganan pengaduan kepada Presiden RI. 
Tinjauan Pustaka

\section{a. Kapasitas Kelembagaan}

Berbagai teori kapasitas kelembagaan menunjukan bahwa penguatan kapasitas pada organisasi sangatlah penting, termasuk di instansi pemerintahan. Pada tahun 1990, pembangunan kapasitas mulai menjadi perhatian pemerintah. Berbagai ahli lain menyebut pembangunan kapasitas dengan berbagai istilah seperti organizational capacity development, capacity strengthening, capacity building, dst. Meskipun demikian, seluruh istilah tersebut menunjukan suatu benang merah yang sama. Sebelum membahas penguatan kapasitas, perlu dipahami konsep capacity itu sendiri. Kapasitas mengarahkan organisasi pada suatu perubahan, oleh karena itu istilah capacity merujuk pada kapabilitas untuk melakukan hal-hal tertentu (Floden et al., 2012).

Daniel Rickett (Jenivia Dwi Ratnasari, Mochamad Makmur, 2016) mengungkapkan bahwa kapasitas kelembagaan bertujuan untuk mewujudkan organisasi lebih kuat dalam mencapai tujuan dan misi. Menurut Grindle (Haryono, 2012), penguatan kapasitas juga merupakan suatu upaya yang dimaksudkan untuk pengembangan berbagai strategi guna meningkatkan efisiensi, efektivitas, dan responsivitas pemerintah. Upaya tersebut dilakukan secara sengaja dan terencana dan dirasakan sebagai suatu kebutuhan untuk mencegah ketidapastian maupun peningkatan kemampuan. Dari definisidefisini tersebut menunjukan bahwa penguatan kapasitas sebagai suatu proses bagi organisasi untuk mencapai tujuan dan sasaran organisasi.

Konsep pembangunan kapasitas ini terus berkembang dari masa ke masa dengan fokus/dimensi yang berbeda-beda. Misalnya, UNDP (Overview of UNDP's Approach to pp Supporting Capacity Development Capacity Development Group Bureau for Development Policy United Nations Development Programme, 2009) melihat bahwa untuk membangun kapaitas harus dilakukan di berbagai tingkatan seperti tingkat individu, kelembagaan, dan sistem. Sama halnya dengan UNDP tersebut, Lustaus (Lusthaus, Adrien, Anderson, \& Carden, 1999) menyebutkan sejumlah aspek dalam kerangka kapasitas di antaranya sumber daya manusia, manajemen keuangan, proses organisasional, kepemimpinan, manajemen, infrastruktur, dan jejaring.

Horton, et.al melihat bahwa dalam pengembangan kapasitas pada organisasi di era yang sangat dinamis ini membutuhkan pergeseran paradigma. Pada masa lalu, pendekatan pengembangan kapasitas lebih berfokus pada individu daripada organisasi. Oleh karena itu menurut Horton, et. al (Horton et al., n.d.) "growing concern for relevance means that the research and development organization need to develop new capacities for management....later on capacity development efforts shifted to focus on software". Capacity development menurut Horton tersebut bertujuan untuk meningkatkan potensial kinerja suatu organisasi sebagai refleksi dari sumber data yang dimiliki dan manajemennya. Oleh karena itu, kapasitas organisasi dapat diklasifikasikan ke dalam 2 komponen yaitu dimensi sumber daya dan dimensi manajemen.

Dimensi sumber daya meliputi berbagai subdimensi seperti pelaksana, infrastruktur, dan teknologi. Sedangkan dimensi manajemen terdiri dari kepemimpinan, program dan proses manajemen, serta jejaring. Berdasarkan konsep organizational capacity development tersebut disusun operasionalisasi konsep pada tabel 1 berikut:

\section{Tabel 1 Operasionalisasi Konsep}

\begin{tabular}{|l|l|l|l|}
\hline Variabel & Dimensi & Subdimensi & Indikator \\
\hline Organizational & Kapasitas & Sumber Daya & 1. Pemahaman SDM mengenai sistem prosedur kerja \\
Capacity & Sumber & Manusia & 2. Kemampuan SDM dalam menjalankan tugas dan \\
Development & Daya & & tanggung jawabnya sesuai dengan aturan yang berlaku \\
& Horton, et & & 3. Penyediaan pelatihan-pelatihan yang mendukung \\
& al, 2003); & & pengetahuan dan keterampilan SDM dalam \\
\hline
\end{tabular}




\begin{tabular}{|c|c|c|}
\hline \multirow[t]{2}{*}{$\begin{array}{l}\text { (Lusthaus, } \\
\text { 1995); }\end{array}$} & & $\begin{array}{l}\text { menjalankan tugas dan fungsinya } \\
\text { 4. Keikutrsertaan SDM dalam mengidentifikasi masalah- } \\
\text { masalah untuk meningkatkan kinerja organisasi } \\
\text { 5. Komunikasi antar SDM terkait masalah yang dihadapi } \\
\text { dalam menjalankan tugas dan fungsi }\end{array}$ \\
\hline & $\begin{array}{l}\text { Sumber Daya } \\
\text { Teknologi }\end{array}$ & $\begin{array}{l}\text { 1. Ketersediaan sumber daya teknologi yang memenuhi } \\
\text { kebutuhan organisasi dalam menjalankan tugas } \\
\text { 2. Pemanfaatan sumber daya teknologi informasi dalam } \\
\text { mendukung tugas dan fungsi organisasi } \\
\text { 3. Kendala-kendala yang dihadapi dalam pemanfaatan } \\
\text { teknologi yang ada }\end{array}$ \\
\hline \multirow[t]{3}{*}{$\begin{array}{l}\text { Kapasitas } \\
\text { Manajemen } \\
\text { (Horton, et } \\
\text { al, 2003); } \\
\text { (Lusthaus, } \\
\text { 1995); } \\
\text { ((Ahmad et } \\
\text { al., 2015) }\end{array}$} & $\begin{array}{l}\text { Program dan } \\
\text { Proses } \\
\text { Manajemen }\end{array}$ & $\begin{array}{l}\text { 1. Pelaksanaan penyusunan rencana kegiatan organisasi } \\
\text { terkait program, kebijakan, sistem, maupun prosedur } \\
\text { yang akan dilakukan oleh organisasi } \\
\text { 2. Kesesuaian antara pelaksanaan program/kegiatan, } \\
\text { kebijakan, sistem, prosedur dengan yang direncanakan } \\
\text { sebelumnya } \\
\text { 3. Kualitas kebijakan/prosedur yang menjadi dasar } \\
\text { penyelenggaraan kinerja dan berhubungan dengan } \\
\text { tujuan organisasi } \\
\text { Adanya pengawasan dan evaluasi terhadap kegiatan- } \\
\text { kegiatan yang dijalankan dan permasalahan- } \\
\text { permasalahan organisasi }\end{array}$ \\
\hline & $\begin{array}{l}\text { Kepemimpinan } \\
\text { Stratejik }\end{array}$ & $\begin{array}{l}\text { 1. Peran pemimpin dalam pembuatan visi, misi, rencana } \\
\text { strategis organisasi, dsb } \\
\text { 2. Peran pemimpin dalam mengarahkan, memobilisasi, } \\
\text { dan mengembangkan motivasi kerja pada sumber daya } \\
\text { manusia } \\
\text { 3. Pemimpin terbuka terhadap adanya perubahan- } \\
\text { perubahan yang muncul dari luar } \\
\text { 4. Pemimpin mengidentifikasi dan menilai kebutuhan dan } \\
\text { peluang organisasi }\end{array}$ \\
\hline & Jejaring & $\begin{array}{l}\text { 1. Adanya kerja sama yang melibatkan unsur organisasi } \\
\text { lain } \\
\text { 2. Adanya mekanisme pertukaran informasi, pengalaman, } \\
\text { dan sumber daya lain antar organisasi } \\
\text { 3. Pemanfaatan hasil tukar informasi bagi organisasi }\end{array}$ \\
\hline
\end{tabular}

Sumber: Horton, et.all, 2003

\section{b. Penanganan Pengaduan Masyarakat (Public Complaint Handling)}

Pengaduan masyarakat pada umumnya diartikan sebagai bentuk kekecewaan/ketidakpuasan publik terhadap suatu output/produk yang dihasilkan termasuk penanganan pengaduannya. Bagi organisasi, pengaduan masyarakat merupakan hal yang penting sebagai sarana input/koreksi dalam rangka meningkatkan kualitas pelayanan organisasi. Hal ini sejalan dengan pernyataan Blackmore (Wibawa, 2009), bahwa mekanisme pengaduan adalah manifestasi vital dalam semangat reformasi sektor publik, oleh karena itu paradigma dalam memandang pengaduan tidak selalu hal yang berkonotasi negatif. Faulkner (2003) menambahkan bahwa volume pengaduan menandakan suatu indikator penting dalam melihat pemberian kualitas layanan.

Sistem pengelolaan pengaduan masyarakat harus dimiliki oleh organisasi untuk mewujudkan penanganan pengaduan yang komprehensif. Adapun tahapantahapan pengaduan di antaranya:

1. penerimaan melalui via telepon, online, email, surat, media sosial, dsb; 
2.Pencatatan terkait data atau informasi sebagai data dukung pengaduan;

3.Konfirmasi tindak lanjut pengaduan;

4.Analisis pengaduan; dst

Selain pembuatan kebijakan dan prosedur dalam penanganan pengaduan, aspek Metode Penelitian

Penelitian ini menggunakan pendekatan post positivisme dengan metode kualitatif yaitu wawancara mendalam dan studi dokumentasi. Wawancara mendalam dilakukan kepada sejumlah pihak yang terkait dengan penelitian baik di lingkungan Kementerian Sekretariat Negara maupun instansi pengelola pengaduan yang merupakan mitra dalam penanganan pengaduan masyarakat kepada Presiden RI meliputi Kementerian Agraria dan Tata Ruang/Badan Pertanahan Nasional, Kementerian Dalam Negeri, Kepolisian RI, perwakilan instansi daerah, dst. Pemilihan instansi tersebut sehubungan dengan jenis permasalahan terbanyak yang diadukan kepada Presiden RI seperti masalah hukum, agraria, dan pelayanan publik. Selain melakukan wawancara mendalam, peneliti juga melakukan tinjauan literatur dari berbagai dokumen, seperti aturan mengenai pengelolaan pengaduan, notulensi rapat, data statistik, laporan akuntabilitas kinerja, laporan tahunan, Rencana Strategis, laporan kegiatan rapat koordinasi, dst.

\section{Hasil dan Pembahasan}

\section{a. Profil Asisten Deputi Pengaduan Masyarakat}

Asisten Deputi Pengaduan Masyarakat merupakan unit kerja setingkat Eselon 2 di Kementerian Sekretariat Negara yang berwenang menyelenggarakan penanganan pengaduan masyarakat kepada Presiden, Wakil Presiden, dan/atau Menteri Sekretaris Negara sebagaimana diatur dalam Peraturan Menteri Sekretaris Negara Nomor 3 Tahun 2015 tentang Organisasi dan Tata Kerja Kementerian Sekretariat Negara. Adapun fungsi yang dijalankan untuk mendukung tugas tersebut, yakni melakukan penerimaan, pencatatan, penelaahan, konfirmasi, klarifikasi, penelitian, penting lain dalam penanganan pengaduan ialah kecukupan dan kemampuan SDM dalam penanganan pengaduan. SDM dituntut untuk dapat mengidentifikasi masalah, memiliki skill untuk merespons, dsb.

pemeriksaan, penyampaian rekomendasi, evaluasi pelaporan, tindak lanjut, dan pengarsipan pengaduan masyarakat, pemantauan perkembangan tindak lanjut, pengoordinasian, dan fungsi lain. Sebelum dibentuk unit tersebut, surat-surat pengaduan masyarakat kepada Presiden terdistribusi ke berbagai unit di Kementerian Sekretariat Negara sehingga pengaduan masyarakat belum terkelola secara terpadu. Dalam penanganan pengaduan, unit kerja tersebut memiliki karakteristik yang berbeda dengan unit pengelola pengaduan lainnya, di antaranya:

1. Pengaduan masyarakat yang diterima ditujukan kepada Presiden;

2. Media pengaduan masyarakat baik surat fisik maupun elektronik;

3. Substansi permasalahan yang diadukan sangat beragam;

4. Substansi pengaduan mayoritas tidak terkait pengaduan di lingkungan Kementerian Sekretariat Negara, jikapun ada menjadi ranah Inspektorat Kementerian Sekretariat Negara;

5. Penyelesaian pengaduan ada pada kewenangan instansi teknis.

Untuk dapat mendukung fungsi dalam penanganan pengaduan, maka perlu diimbangi dengan kekuatan struktur organisasi. Adapun bidang-bidang dalam struktur Asisten Deputi Pengaduan Masyarakat sesuai dengan fungsi dan mengakomodasi permasalahanpermasalahan yang diadukan, seperti Bidang Hukum dan HAM, Bidang Agraria dan Lingkungan Hidup, Bidang Pelayanan Publik, Aparatur, dan Ketenagakerjaan, serta Bidang Data, Evaluasi, dan Pelaporan, dengan jumlah keseluruhan SDM sebanyak 30 orang. Sejak tahun 2016 terjadi perubahan Indikator Kinerja Utama Asisten Deputi Pengaduan Masyarakat, yang 
menjadikan perannya lebih strategis terkait upayanya dalam mendorong penyelesaian pengaduan di instansi terkait. Dalam menjalankan proses bisnis sehari-hari, Asisten Deputi Pengaduan Masyarakat mengacu pada Standard Operating Procedures (SOP) dan Standar Pelayanan Penanganan Pengaduan Masyarakat serta Pemantauan Tindak Lanjut Pengaduan. Untuk mempermudah klasifikasi masalah dan mengatur penatausahaannya, maka digunakan pedoman Peraturan Menteri Pendayagunaan Aparatur Negara dan Reformasi Birokrasi Nomor 5 Tahun 2009 tentang Pedoman Umum Penanganan Pengaduan Masyarakat bagi Instansi Pemerintah. Sampai saat ini pedoman tersebut masih menjadi rujukan penanganan pengaduan masyarakat kepada Presiden RI.

\section{a. Analisis}

Merujuk pada teori Organizational Capacity Development menurut Horton, et.al, penulis melihat kondisi yang relevan antara teori tersebut dengan permasalahan kapasitas kelembagaan dalam penanganan pengaduan masyarakat kepada Presiden RI. Adapun dalam analisis ini peneliti akan mengurai sejumlah kapasitas yang perlu diperkuat oleh Asisten Deputi Pengaduan Masyarakat berdasarkan identifikasi sejumlah factual problem yang ada pada unit kerja tersebut.

\section{a. Dimensi Sumber Daya}

Pada dimensi ini, terdapat subdimensi sumber daya manusia (SDM) dan teknologi.

\section{Sumber Daya Manusia}

Terkait kapasitas SDM, Fitzsimmons (2001) melihat bahwa kapasitas tersebut terkait dengan segi kuantitas dan kualitas. Keduanya berpengaruh pada kinerja organisasi. Secara kuantitas, SDM di lingkungan unit kerja Asisten Deputi Pengaduan Masyarakat telah cukup memadai. Namun demikian, kuantitas yang memadai harus diiringi pula dengan kapasitas kemampuan SDM yang sesuai dengan kebutuhan organisasi. Menurut pedoman Ombudsman New South Wales
(2017), bahwa dalam menjalankan tugas penanganan pengaduan, terdapat beberapa hal yang perlu dipersiapkan bagi SDM di antaranya kemampuan skill untuk merespons pengaduan dan mengadapi pengaduan yang diterimanya, menyadari kebijakan dan prosedur, memperoleh pelatihan yang efektif, dan terdapat pedoman tertulis yang jelas.

Pada umumnya SDM di unit kerja Asisten Deputi Pengaduan Masyarakat telah memahami sistem dan prosedur serta proses bisnis dalam penanganan pengaduan, akan tetapi dalam pelaksanaanya belum dapat secara optimal memenuhi prosedur yang berlaku. Jumlah surat pengaduan kepada Presiden RI yang terus meningkat dan adanya aktivitas lain yang harus dijalankan SDM seperti salah satunya memberikan pelayanan secara langsung kepada masyarakat menjadi salah satu kendala bagi pegawai untuk dapat menangani pengaduan sesuai ketentuan yang berlaku.

Kondisi pekerjaan yang sangat dinamis dan pengaduan yang sangat kompleks sangat membutuhkan kapasitas SDM yang mumpuni. Keterbatasan kemampuan SDM tentu akan mempengaruhi kinerja dan kesiapan SDM dalam memberikan pelayanan. Gull et al (Monizsya, n.d.) menyatakan bahwa upaya penguatan dan penciptaan pengetahuan bagi SDM seharusnya diatur oleh organisasi melalui program-program, baik program pendidikan formal maupun informal. Program-program tersebut akan menjadi bekal untuk menunjang kapasitasnya dalam menjalankan tanggung jawab. Hal ini sejalan dengan pendapat $\mathrm{Wu}$ (Monizsya, n.d.)

bahwa pelatihan berbasis kompetensi akan meningkatkan pengetahuan, keterampilan, dan sikap SDM sehingga akan lebih terstruktur dan terarah. Namun demikian, pada praktiknya program pendidikan dan pelatihan (diklat) yang menunjang kapasitas SDM dalam menangani pengaduan masih terbatas.

Selama ini program diklat yang diselenggarakan secara reguler merupakan diklat yang berbasis pengetahuan umum. Sedangkan program khusus yang menunjang 
tugas dan fungsi unit kerja relatif terbatas dan hanya dapat diikuti oleh perwakilan dari unit tersebut, misalnya diklat public speaking, pelayanan prima, conflict resolution, mediasi, dsb. Kondisi demikian akan menjadi suatu kendala khususnya bagi pegawai baru yang tidak memiliki pengetahuan dasar dalam penanganan pengaduan mengingat latar belakang pendidikan setiap pegawai sangat beragam. Selama ini kemampuan pegawai diperoleh secara mandiri, seperti melakukan analisis dari media online, berbagai aturan, berdiskusi/sharing knowledge dengan rekan kerja maupun yang telah mengikuti diklat, serta berkomunikasi dengan masyarakat maupun instansi.

Upaya penguatan kapasitas secara informal tersebut tentu akan lebih komprehensif jika ditunjang dengan upaya penguatan secara formal. Menurut Kepala Subbidang Pertanahan dan Perumahan Asisten Deputi Pengaduan Masyarakat, seluruh pegawai idealnya memiliki skill dan kompetensi untuk berkomunikasi dan memberikan pelayanan, dimana itu semua dapat terwujud jika ditunjang dengan pelatihan secara terus menerus. Pendapat tersebut sejalan dengan pendapat Haryono (2012) bahwa untuk menjaga kualitas SDM maka setidaknya SDM memperoleh pelatihan sesuai kompetensi setahun sekali, hal ini guna mempersiapkan SDM menghadapi tantangan-tantangan ke depan di kemudian hari.

Penyelenggaraan pelatihan ini merupakan bagian dari dukungan organisasi terhadap kemajuan kapasitas SDM. Penguatan kapasitas SDM melalui diklat ini sejatinya menunjukan upaya penguatan kapasitas pengetahuan di tingkat individu, dan belum berbicara pada tingkatan kapasitas pengetahuan pada organisasi yang mana dapat berimplikasi pada keberlangsungan organisasi.

Organisasi perlu melakukan proses identifikasi dan pemetaan kebutuhan unit kerja dan menjadi pertimbangan akan pentingnya penyelenggaraan programprogram yang mendukung kapasitas pengetahuan tingkat individu maupun organisasi dalam penyelenggaraan penanganan pengaduan. Proses identifikasi tersebut dapat dilakukan, misalnya melalui pelibatan SDM yang selama ini memiliki kesempatan dan peluang untuk mengkomunikasikan permasalahan dan kebutuhan kepada pimpinan.

\section{Sumber Daya Teknologi}

Keberadaan teknologi dalam suatu organisasi sangat penting guna menghasilkan output pekerjaan lebih cepat, tepat, dan mudah. Dalam konteks penanganan pengaduan, dukungan teknologi digital tidak dapat dinomorsekiankan karena di era globalisasi segalanya dituntut cepat dan dinamis. Dalam penyelenggaraan penanganan pengaduan masyarakat kepada Presiden RI, keberadaan dan pemanfaatan teknologi merupakan salah satu upaya yang dapat memperkuat kapasitas penanganan pengaduan di lingkungan unit kerja Asisten Deputi Pengaduan Masyarakat. Dalam kesehariannya unit kerja tersebut telah memanfaatkan penggunaan sistem aplikasi berbasis web dalam menjalankan tugas kesehariannya, hanya saja perlu pengembangan lebih lanjut pada sistemsistem yang telah diterapkan tersebut agar dapat optimal memenuhi kebutuan unit kerja. Adapun sejumlah sistem yang diterapkan antara lain Sistem Pemerintahan Berbasis Elektronik (SPBE), Aplikasi Pengaduan Masyarakat atau Aplikasi Dumas, dan Sistem Pengecekan Surat melalui Website

Kemajuan teknologi digital pada prinsipnya memberikan kemudahan dan menciptakan pengelolaan pengaduan lebih canggih. Adanya aplikasi berbasis web sejatinya dapat mengatasi kendala soal keterbatasan waktu dan ruang karena segala sesuatunya dapat diakses dan diperbarui kapanpun dan dimanapun. Di lingkungan Kementerian Sekretariat Negara aplikasi berbasis web untuk pendisposisian surat telah dimanfaatkan unit-unit kerja melalui sistem bernama Sistem Persuratan dan Disposisi Elektronik Open (SPDE Open). Sistem tersebut berguna untuk 
mentransformasikan pengiriman surat maupun pemberian disposisi melalui sistem. Tujuan pemanfaatan sistem tersebut tidak lain agar pemrosesan surat pengaduan masyarakat dapat lebih cepat dan mengatasi kendala pengiriman surat fisik yang melampaui SOP. Namun demikian, sistem yang ada saat ini masih memiliki keterbatasan teknis seperti sistem eror dan masih perlu penyesuaian format, sehingga pemrosesan surat pengaduan masih dilakukan baik secara manual maupun sistem, yang artinya belum dapat membawa ke arah efisiensi dalam bekerja. Oleh karena itu, adanya penguatan kapasitas sistem melalui pengembangan aplikasi ini sejatinya dapat menjadi solusi atas kendala pengiriman surat melalui cara konvensional.

Aplikasi berbasis web lainnya yang saat ini mendukung fungsi penanganan pengaduan dan membutuhkan pengembangan ialah Sistem Aplikasi Internal Dumas. Sistem tersebut merupakan database surat-surat pengaduan masyarakat kepada Presiden RI berbasis aplikasi. Aplikasi ini mengkonversikan database dalam bentuk Microsoft Excel yang digunakan sebelum tahun 2013. Namun demikian, keberadaan aplikasi tersebut belum dapat secara optimal memenuhi kebutuhan unit kerja. Output yang dihasilkan belum dapat secara otomatis menghasilkan informasi data statistik yang akan kemudian menjadi bahan analisis dan disajikan dalam bentuk laporan penanganan pengaduan masyarakat kepada Presiden RI sehingga untuk mengolahnya masih dilakukan secara manual. Oleh karena itu perlu adanya pengembangan fungsi sistem yang dapat mendukung proses penyusunan data dan informasi pengaduan yang komprehensif, cepat, tepat, dan akurat untuk dijadikan sebagai bahan rekomendasi pengambilan kebijakan bagi pucuk pimpinan tertinggi, karena sejak aplikasi tersebut dibangun pada tahun 2013 belum ada pengembangan yang berarti sampai saat ini. Selain fungsi sebagai database, pemanfaatan sistem teknologi Aplikasi Dumas juga dapat mendukung penguatan sistem monitoring penanganan pengaduan masyarakat kepada Presiden RI. Sistem dapat berfungsi sebagai "warning sign" bagi unit kerja dalam rangka menindaklanjuti perkembangan penanganan pengaduan dengan instansi terkait. Pada praktiknya sistem belum memenuhi fungsi tersebut sehingga proses monitoring selama ini dilakukan secara manual melalui pengkroscekan data oleh SDM.

Selain kedua aplikasi tersebut, upaya penguatan kapasitas penanganan pengaduan di unit kerja Asisten Deputi Pengaduan Masyarakat juga terletak pada pengembangan sistem pengecekan surat berbasis web. Cakupan pengaduan masyarakat kepada Presiden RI yang berskala nasional, hendaknya ditunjang dengan media berupa sistem yang dapat membantu masyarakat untuk melakukan pengecekan surat. Namun demikian, proses pengecekan pengaduan selama ini hanya dapat dilakukan secara manual dengan mendatangi Biro TU Persuratan Kementerian Sekretariat Negara untuk kemudian diarahkan kepada unit kerja Asisten Deputi Pengaduan Masyarakat. Adanya sistem tentu akan memberikan kemudahan bagi masyarakat untuk memperoleh informasi perkembangan penanganan. Pengecekan melalui sistem selama ini terkendala hal teknis seperti keterbatasan kapasitas sistem untuk dapat beroperasi secara real time maupun belum adanya aturan main pengecekan melalui sistem. Menurut Kepala Subbidang Pengolahan Data Asisten Deputi Pengaduan Masyarakat, upaya untuk memperkuat sistem ini sejatinya membutuhkan dukungan teknologi dari pemimpin karena dukungan tersebut sekaligus akan menentukan sejauh mana keterbukaan dalam penanganan pengaduan masyarakat kepada Presiden RI.

\section{b. Dimensi Manajemen}

Horton, et. al menjelaskan bahwa dalam penguatan kapasitas organisasi selain membutuhkan dukungan sumber daya juga membutuhkan manajemen program. Manajemen program menunjukan kemampuan organisasi dalam 
mengembangkan program yang mendukung misi. Menurut Contreras (Haryono, dkk, 2012), kesuksesan organisasi juga dipengaruhi oleh aturan dan sistem manajemen yang dijalankan. Hal ini terjadi pada unit kerja Asisten Deputi Pengaduan Masyarakat yang perlu memperkuat 3 subdimensi, di antaranya program dan proses manajemen, kepemimpinan yang strategis, dan hubungan/network.

\section{Program dan Proses Manajemen}

Subdimensi ini menunjukan kemampuan pengembangan dan pengadministrasian program-program yang dapat mendukung misi organisasi. Upaya pengembangan ini dilakukan mulai dari penyusunan sampai pada evaluasi program. Di lingkungan unit kerja Asisten Deputi Pengaduan Masyarakat, proses penyusunan rencana program dilakukan oleh Bidang Data, Evaluasi, dan Pelaporan pada awal tahun dengan mempertimbangkan hasil proses evaluasi pelaksanaan kegiatan sebelumnya. Dalam praktiknya, proses kesesuaian pelaksanaan dengan penyusunan selama ini terkendala anggaran sehingga perlu penyesuaian kembali untuk dapat mewujudkan programprogram baru. Keterbatasan tersebut berimplikasi pada hasil penyusunan rencana yang sebagian besar berisi kegiatan rutinitas seperti tahun-tahun sebelumnya. Sementara dalam menangani pengaduan masyarakat biasanya juga dihadapkan pada kebutuhan model-model penanganan tertentu sebagai suatu terobosan yang mungkin belum masuk dalam penyusunan rencana sebelumnya. Oleh karena itu, diharapkan penguatan kapasitas dalam penyusunan rencana secara komprehensif dapat mengakomodir tugas dan fungsi penanganan pengaduan seutuhnya

Pencapaian keberhasilan suatu organisasi ditentukan tidak hanya dari desain suatu rencana saja, melainkan juga pelaksanaan dari rencana tersebut. Pelaksanaan tugas dan fungsi Asisten Deputi Pengaduan Masyarakat dalam menyelenggarakan penanganan pengaduan masyarakat mengacu pada Standar
Pelayanan Pengaduan Masyarakat, Standar Pelayanan Pemantauan Tindak Lanjut Pengaduan Masyarakat, dsb. Terkait pedoman untuk penanganan pengaduan masyarakat, Asisten Deputi Pengaduan Masyarakat menggunakan Peraturan Menteri Pendayagunaan Aparatur Negara (Permenpan) Nomor PER/05/M.PAN/4/2009 tentang Pedoman Umum Penanganan Pengaduan Masyarakat bagi Instansi Pemerintah. Pedoman tersebut diperuntukan bagi instansi pemerintah dalam menyelenggarakan penanganan pengaduan masyarakat di lingkungan instansinya. Pedoman tersebut mengatur pengelolaan pengaduan mulai dari pencatatan sampai pengarsipan, pembuktian pengaduan, penyusunan hasil penanganan pengaduan, dan koordinasi penanganan pengaduan, serta pelaporan hasil penanganan pengaduan.

Namun, dalam praktiknya pedoman tersebut belum sepenuhnya dapat mendorong instansi untuk melaporkan hasil penanganannya kepada Presiden RI maupun menyelesaikan pengaduannya, sehingga sebagai salah satu alternatif upaya bagi Asisten Deputi Pengaduan Masyarakat untuk mendorong penyelesaian tersebut ialah dengan metode jemput bola berupa fungsi pemantauan langsung dan pemutakhiran data dengan instansi-instansi terkait. Upaya tersebut dilakukan mengingat tuntutan penyelesaian dan keterbukaan informasi kepada masyarakat semakin hari semakin kuat.

Menurut Kepala Subbidang Evaluasi dan Pelaporan Asisten Deputi Pengaduan Masyarakat, dalam penyelenggaraan penanganan pengaduan masyarakat kepada Presiden RI ini sangat dibutuhkan pedoman yang secara khusus mengatur penanganan pengaduan tersebut sebagai petunjuk teknis bagi instansi terkait sekaligus dasar penyelenggaraan penanganan pengaduan masyarakat kepada Presiden RI. Hal ini didukung oleh pernyataan Asisten Deputi Pengaduan Masyarakat bahwa "pengaduan ini ditujukan kepada Presiden RI, ketika pengaduan ini tidak ada respons balik nanti opini masyarakat kepada Presiden tidak 
bisa menyelesaikan, sementara hampir sетиa penyelesaiannya kewenangannya bukan kepada Presiden RI, tetapi instansi terkait. Meski secara ketatanegaraan bukan di bawah Presiden tetapi secara hierarki mereka tidak bertanggungjawab langsung kepada Presiden RI sehingga ketika tidak merespon atau telat kita tidak punya pegangan atau tali untuk mengikat berdasarkan ini kamu harus ini" (Wawancara dengan Hadi Nugroho, 11 Desember 2019).

Hal ini sejalan dengan pernyataan peserta perwakilan instansi dalam kegiatan focal point penanganan pengaduan masyarakat kepada Presiden RI yang diselenggarakan di Provinsi Sumatera Selatan pada tanggal 19 September 2019, bahwa adanya pedoman penanganan pengaduan masyarakat kepada Presiden RI akan memberikan pemahaman kepada instansi yang memperoleh pelimpahan pengaduan dari Kementerian Sekretariat Negara untuk selanjutnya ditindaklanjuti dan dilaporkan hasil penanganannya. Dari pernyataan-pernyataan tersebut, menunjukan bahwa kebutuhan payung hukum bagi penyelenggaraan penanganan pengaduan masyarakat kepada Presiden RI ialah dalam rangka mendorong penyelesaian pengaduan oleh instansi berwenang maupun membangun kepercayaan masyarakat terhadap pemerintahan serta mewujudkan efektivitas pengelolaan pengaduan itu sendiri.

Dalam proses manajemen di suatu organisasi juga perlu adanya evaluasi untuk mengetahui keunggulan dan kelemahan pada instansi. Evaluasi juga bertujuan agar organisasi dapat mengidentifikasi kebutuhan di masa yang akan datang. Proses evaluasi yang dilakukan unit kerja Asisten Deputi Pengaduan Masyarakat berlangsung cukup rutin melalui kegiatan rapat internal dan adanya laporan bulanan yang disusun oleh setiap bidang. Adanya laporan ini akan mengidentifikasi kesalahan dan kelemahan serta menjadi input bagi penyusunan rencana kerja berikutnya oleh Bidang Data, Evaluasi, dan Pelaporan. Namun demikian, proses evaluasi yang berjalan selama ini lebih fokus pada penyelesaian satuan pengaduan dan proses bisnis sehari-hari. Oleh karena itu, proses evaluasi perlu didorong untuk mengoptimalkan fungsi Asisten Deputi Pengaduan Masyarakat lebih luas.

Selain itu, penguatan kapasitas unit kerja tersebut juga memerlukan evaluasi pada fungsi koordinasi penanganan pengaduan masyarakat dengan instansi terkait. Berdasarkan laporan evaluasi kegiatan focal point penanganan pengaduan masyarakat pada tahun 2019, disebutkan bahwa beberapa kendala yang timbul dalam penanganan pengaduan masyarakat kepada Presiden RI berkaitan dengan koordinasi antar instansi serta belum efektifnya penyampaian surat secara fisik selama ini.

Berdasarkan uraian di atas, upaya penguatan kapasitas dalam proses manajemen ini sangat diperlukan untuk mendesain kembali cara/upaya untuk menyelenggarakan penanganan pengaduan yang efisien dan efektif. Proses penyusunan rencana harus dapat mendorong tugas dan fungsi penyelenggaraan penanganan pengaduan berjalan optimal, disertai dengan pelaksanaan yang berdasarkan aturan/pedoman $\mathrm{n}$ yang semakin memperkuat tugas dan fungsi, dan juga evaluasi yang komperehensif terhadap penyelenggaraan tugas dan fungsi selama ini.

\section{Kepemimpinan yang Strategik}

Dalam suatu organisasi, kepemimpinan merupakan salah satu aspek yang memegang peranan untuk membawa organisasi ke arah pencapaian visi. Kepemimpinan yang strategis dibutuhkan karena memiliki kapasitas untuk menilai dan menafsirkan kebutuhan dan peluang di luar organisasi, menetapkan arah, memotivasi, dsb.

Di lingkungan unit kerja Asisten Deputi Pengaduan Masyarakat, peran kepemimpinan yang kuat sangat dibutuhkan untuk mewujudkan representasi "mata dan telinga Presiden". Pemimpin harus bersikap dinamis, terbuka, dan solutif terhadap dinamika lingkungan yang terjadi, baik 
aspek sosial, hukum, teknologi, budaya, dsb. Hal ini karena keputusan yang diambil akan menentukan bagaimana organisasi di kemudian hari.

Pimpinan Asisten Deputi Pengaduan Masyarakat selalu terlibat dalam pembuatan visi, misi, laporan akuntabilitas, dan rencana stratejik organisasi. Begitupun dengan keterbukaannya pada setiap perubahan di lingkungan, misalnya adanya dorongan pimpinan terhadap pemanfaatan sistem surat secara elektronik yang disediakan oleh Kementerian Sekretariat Negara dan pengintegrasian sistem Aplikasi Dumas dengan Sistem LAPOR!. Pimpinan Asisten Deputi Pengaduan Masyarakat berupaya melihat adanya peluang dan kesempatan bagi unit kerja dalam melakukan kerja sama untuk menyelenggarakan kegiatan penanganan pengaduan masyarakat dengan instansi yang kerap menjadi mitra dalam penanganan pengaduan. Hal ini disadari karena keterbatasan unit kerja untuk dapat menyelenggarakan penanganan pengaduan tanpa melibatkan instansi. Sebagai contoh ialah kegiatan penguatan focal point bersama inspektorat daerah, kerja sama dengan Kementerian Dalam Negeri dalam mengkroscek data penanganan pengaduan dalam kegiatan Tindak Lanjut Hasil Pemeriksaan yang merupakan agenda rutin tahunan yang dilakukan oleh Kementerian Dalam Negeri, dsb.

Menurut Kepala Subbidang Pengolahan Data Asisten Deputi Pengaduan Masyarakat, dukungan pimpinan di level unit kerja sejauh ini sudah cukup optimal dalam penyelenggaraan tugas dan fungsi Asisten Deputi Pengaduan masyarakat, namun demikian untuk mewujudkan penanganan pengaduan yang lebih handal dan profesional ini dibutuhkan dukungan yang lebih kuat dan memadai dari pucuk pimpinan tertinggi.

\section{Hubungan Kerja Sama dengan Instansi Terkait \\ Menurut Millen (2001), kerja sama menjadi paradigma baru dalam berpikir tentang capacity building. Lebih lanjut,}

Horton, et.al menyebutkan bahwa salah satu aspek kapasitas manajemen yang mempengaruhi kelembagaan ialah melalui pengembangan networking. Konsep networking mengedepankan bahwa sebuah kelompok atau organisasi saling bertukar informasi untuk memastikan pencapaian outcome. Pengembangan jejaring ini dianggap sebagai salah satu cara efektif untuk mengatasi masalah karena kapasitas jejaring akan menunjukan kemampuan organisasi dalam berinteraksi dan bekerja sama. Begitupun dalam penanganan pengaduan masyarakat kepada Presiden RI. Sebagaimana telah penulis urai sebelumnya bahwa kewenangan dalam penyelesaian penanganan pengaduan masyarakat kepada Presiden RI yang hampir seluruhnya ada pada instansi terkait mendorong perlunya penguatan kapasitas jejaring dengan instansi terkait maupun satuan organisasi di lembaga kepresidenan yang juga kerap mendapatkan pengaduan dari masyarakat.

Di lingkungan lembaga kepresidenan, unit kerja Asisten Deputi Pengaduan Masyarakat melakukan koordinasi dengan beberapa unit kerja/satuan organisasi terkait penanganan pengaduan, misalnya dengan Sekretariat Wakil Presiden, Deputi Bidang Hukum dan Perundang-Undangan, Kantor Staf Presiden, dan Sekretariat Kabinet. Bentuk koordinasi antar instansi atau unit tersebut selama ini berlangsung dalam bentuk korespondensi maupun secara informal. Koordinasi ini sangat dibutuhkan karena objek pengaduan masyarakat yang sama seringkali ditujukan kepada sejumlah instansi. Oleh karena itu, mekanisme kerja sama dalam penanganan pengaduan ini sangat dibutuhkan untuk tukar menukar informasi penanganan pengaduan agar tidak terjadi tumpang tindih. Hanya saja dalam pelaksanaannya hubungan kerja sama selama ini perlu diperkuat melalui suatu ikatan formal agar ke depan hubungan tersebut dapat berkelanjutan, mengingat kemungkinan adanya pergantian pimpinan atau pegawai di unit kerja tersebut.

Selain kerja sama di lingkungan lembaga kepresidenan, unit kerja Asisten 
Deputi Pengaduan Masyarakat memahami bahwa penanganan pengaduan masyarakat kepada Presiden RI tidak dapat dilakukan secara tunggal. Tanpa adanya kerja sama dengan instansi terkait yang berwenang di seluruh Indonesia pencapaian outcome berupa kepuasan masyarakat terhadap penyelesaian pengaduan tidak akan pernah terwujud. Hal ini karena penanganan pengaduan masyarakat kepada Presiden RI bukan hanya menjadi kepentingan Kementerian Sekretariat Negara, melainkan harus dilihat sebagai kepentingan bersama dalam rangka penanganan pengaduan masyarakat secara nasional dan meningkatkan kepercayaan masyarakat terhadap pemerintah.

Selama ini kerja sama penanganan pengaduan masyarakat kepada Presiden RI dilakukan dalam bentuk korespondensi, rapat koordinasi penanganan pengaduan masyarakat, dan pemantauan tindak lanjut penanganan pengaduan yang hampir sebagian besar terjun ke lokasi pengaduan. Dalam kegiatan rapat tersebut biasanya berlangsung kegiatan pemutakhiran data pengaduan (updating data) karena belum diperolehnya respons/klarifikasi dari instansi terkait yang dilaporkan kepada Kementerian Sekretariat Negara. Namun demikian, salah satu kelemahan dalam hubungan kerja sama penanganan pengaduan masyarakat kepada Presiden RI selama ini ialah belum adanya ikatan/payung hukum yang berimplikasi pada keberlanjutan hubungan. Petunjuk teknis penanganan pengaduan masyarakat kepada Presiden RI selama ini disampaikan secara lisan mengenai tugas dan fungsi Asisten Deputi Pengaduan Masyarakat pada saat kegiatan rapat berlangsung. Menurut Kepala Subbidang Pengumpulan dan Pengolahan Data Asisten Deputi Pengaduan Masyarakat, kondisi demikian mengakibatkan koordinasi seringkali lepas sehingga menjadi salah satu kendala sekaligus tantangan dalam rangka memperoleh klarifikasi dari instansi terkait. Berikut kutipannya "Tidak punya pedoman secara formal dan koordinasi secara formal, tantangannya besar, membutuhkan waktu yang banyak dan effort yang cukup tinggi" (Wawancara dengan Fina Hayati, 4 Desember 2019).

Menyambut pernyataan tersebut, Kepala Bidang Analisa dan Evaluasi Hasil Pengawasan Inspektorat Jenderal Kementerian Dalam Negeri menyampaikan bahwa hubungan kerja sama antara Kementerian Sekretariat Negara dengan instansi terkait misalnya Kementerian Dalam Negeri dalam penanganan pengaduan masyarakat sangat mungkin dilakukan secara formal dalam kaitannya dengan konteks pemerintahan daerah. Kewenangan penyelesaian pengaduan di tingkat pemerintahan daerah dapat dijembatani melalui kerja sama secara terlembaga/formal antara Kementerian Dalam Negeri dan Kementerian Sekretariat Negara, misalnya dalam bentuk Nota Kesepahaman atau Memorandum of Understanding. Hal ini juga didukung oleh perwakilan dari instansi Kepolisian Negara yang menyampaikan bahwa dalam penanganan pengaduan dengan lembaga terkait, instansi Kepolisian telah melakukan hubungan dengan baik di bawah nota kesepahaman tersebut, seperti dengan Ombudsman, Kejaksaan, dsb. Harapannya hubungan yang sama juga dapat dilakukan antara Kementerian Sekretariat Negara dengan Kepolisian dalam mewujudkan efektivitas penanganan pengaduan.

Adanya kesepakatan tersebut dapat membangun komitmen bersama antar pihak dalam menjawabkan hak dan kewajiban sesuai dengan SOP yang berlaku di setiap instansi daerah. Mekanisme tersebut akan lebih mengikat dan efektif dalam penanganan pengaduan masyarakat karena adanya aturan tentang rentang waktu bagi instansi dalam menangani dan melaporkan kepada Presiden RI. Kebutuhan ikatan formal ini juga disampaikan oleh Kepala Subbagian Pemberitaan, Publikasi, dan Media Centre Biro Hukum dan Hubungan Masyarakat Kementerian Agraria dan Tata Ruang/BPN, sebagai salah satu mitra penanganan pengaduan Kementerian 
Sekretariat Negara, bahwa adanya regulasi akan memberikan kemudahan bagi instansi terkait dan menjaga ketertiban administrasi Berikut kutipannya: "jadi menurut saya perlu untuk dituangkan apakah dalam bentuk Permen, Juknis, jadi juga dalam hal tertib administrasi juga tercapai, jadi si pelaksana ga bisa disalahkan misalnya orang ga diatur kok, kami mau seperti ini itu ga diatur, tapi kalo sudah ada aturan si pelaksana bisa berpedoman jadi kalo melenceng dari pedoman kan berarti ada unsur sengaja atau kelalaian, dan terlindungi jugs surat kami." (Wawancara dengan Rizki, 10 Januari 2020).

Adanya kerja sama ini akan mendorong pertukaran informasi satu sama lain dan pemanfaatan informasi tersebut ke depan. Selama menjalankan fungsi pemantauan dan koordinasi dengan instansi terkait, Asisten Deputi Pengaduan Masyarakat kerap melakukan pertukaran informasi baik menyangkut substansi maupun teknis penanganan pengaduan. Misalnya, informasi terkait faktor-faktor yang menjadi alasan keterlambatan atau tidak tertanganinya suatu pengaduan oleh instansi di antaranya keterbatasan anggaran, beban kerja yang tinggi di daerah, berkas fisik yang belum sampai di instansi, dsb. Kendala atau kelemahan tersebut pada prinsipnya dipahami Asisten Deputi Pengaduan Masyarakat. Oleh karena itu dengan adanya mekanisme tukar menukar informasi tersebut maka dilakukan proses negosiasi untuk menjadi pertimbangan dalam penanganan pengaduan masyarakat, misalnya agar dianggarkan untuk tahun berikutnya, dsb. Hasil pertukaran tersebut biasanya dibagikan pada saat kegiatan rapat rutin internal maupun diskusi kasus dalam rangka sharing knolwedge di lingkungan Asisten Deputi Pengaduan Masyarakat.

\section{Kesimpulan}

Dalam rangka penyelenggaraan penanganan pengaduan masyarakat kepada Presiden RI dibutuhkan kapasitas kelembagaan yang mumpuni oleh Asisten Deputi Pengaduan Masyarakat. Kapasitas tersebut diharapkan dapat mencerminkan kelembagaan yang kuat dan strategis sebagai representasi "mata dan telinga Istana", maka demikian penguatan kapasitas perlu diperhatikan ialah baik dari kapasitas sumber daya dan manajemen.

Kapasitas sumber daya meliputi kemampuan SDM dan teknologi sangat berperan besar dalam mendukung tugas dan fungsi unit kerja Asisten Deputi Pengaduan Masyarakat sehingga perlu ditunjang dengan pemberian program pendidikan dan pelatihan secara formal dan berkelanjutan serta pengembangan berbagai sistem teknologi guna memenuhi kebutuhan proses bisnis dalam penanganan pengaduan.

Begitupun dengan kapasitas manajemen, dibutuhkan proses evaluasi secara menyeluruh guna mengidentifikasi peluang dan tantangan dalam penanganan pengaduan di kemudian hari, dukungan dan komitmen pimpinan dalam mewujudkan penyelenggaraan penanganan pengaduan masyarakat kepada Presiden yang optimal, kebutuhan payung hukum sebagai dasar penyelenggaraan penanganan pengaduan serta kerja sama antar instansi pengelola pengaduan yang lebih terkelola dengan baik.

\section{Saran}

1.Penyelenggaraan penanganan pengaduan masyarakat kepada Presiden RI bukan hanya dilihat dari kepentingan kewenangan instansi Kementerian Sekretariat Negara, melainkan lebih luas dari itu, yakni pemahaman konsep penanganan pengaduan secara nasional dan komitmen bersama dalam mewujudkan penyelenggaraan pemerintahan yang akuntabel, transparan, responsif, dan terbuka serta meningkatkan kepercayaan publik.

2. Perlunya kerja sama Kelembagaan atau tata kelola jejaring dalam rangka penanganan pengaduan yang efisien dan efektif serta mencegah terjadinya tumpang tindih. 


\section{Buku}

[1] Haryono, Bambang, dkk. 2012. Capacity Building. Malang: UB Press

[2] Faulkner, M. 2003. Customer Management Excellence. John Wiley \& Sons Limited: Sussex

[3] Wibawa, Samodra. 2009. Administrasi Negara: Isu-Isu Kontemporer. Yogyakarta: Graha Ilmu

\section{Jurnal}

[4] Ahmad, T., Farrukh, F., \& Nazir, S. (2015). Capacity building boost employees performance. Industrial and Commercial Training, 47(2), 6166. https://doi.org/10.1108/ICT-052014-0036

[5] Brewer, B. (2007). Citizen or customer? Complaints handling in the public sector. International Review of Administrative Sciences, 73(4), 549556.

https://doi.org/10.1177/0020852307083 457

[6] Department of Health \& Human Services. (2012). Guide to Complaint Handling in Health Services. 56.

[7] Floden, R. E., Goertz, M. E., Day, J. O., Floden, B. Y. R. E., Goertz, M. E., \& Day, J. O. (2012). Capacity Building in Systemic Reform The authors hope that out the framework analysis is also needed to understand the role capacity and its. 77(1), 19-21.

[8] Frymier, J. (1987). Phi Delta Kappa International. Phi Delta Kappan, 69(1), 8-14.

[9] Heracleous, L., \& Johnston, R. (2009). Can business learn from the public sector? European Business Review, 21(4), 373-379. https://doi.org/10.1108/0955534091097 0454

[10] Horton, D., Alexaki, A., Bennett-lartey, S., Brice, K. N., Campilan, D., Carden, F., ... Duong, L. T. (n.d.). Organizations around the World.
[11] Jenivia Dwi Ratnasari, Mochamad Makmur, H. R. (2016). Pengembangan Kapasitas (Capacity Building) Kelembagaan Pada Badan Kepegawaian Daerah Kabupaten Malang. Jurnal Administrasi Publik Mahasiswa Universitas Brawijaya, l(3), 103-110.

[12] Lusthaus, C., Adrien, M.-H., Anderson, G., \& Carden, F. (1999). Enhancing Organizational Performance - A TOOLBOX FOR SELFASSESSMENT. In Organization Studies (Walter de Gruyter GmbH \& Co. KG.) (Vol. 20). https://doi.org/10.2307/2667047

[13] Monizsya, C. B. (n.d.). KERJA DAN KINERJA KARYAWAN ( Studi Pada Karyawan Bagian Sales Force PT Telkom Indonesia Witel Jatim Surabaya ). 38(1), 74-82.

[14] Milen, A. (2001). What Do We Know About Capacity Building? An Overview of Existing Knowledge and Good Practice. Geneva: World Health Organization

[15] New South Wales Ombudsman. (2017). Effective Complaint Handling Guidelines. Sydney, ISBN 978-1925569-2-9

[16] Overview of UNDP's Approach to pp Supporting Capacity Development Capacity Development Group Bureau for Development Policy United Nations Development Programme. (2009). Retrieved from https://www.undp.org/content/dam/apl aws/publication/en/publications/capaci ty-development/undp-capacitydevelopment-presentation_august2009/Capacity Development UNDP August 2009.pdf

\section{Website}

[17] Menpan.go.id. (2016). Pengaduan: Bentuk Kepedulian Masyarakat terhadap Penyelenggaraan Pemerintahan. https://rbkunwas.menpan.go.id/artikel/artikelrbkunwas/170-pengaduan-bentuk-kepedulian- 
masyarakat-terhadap-penyelenggaraan-

pemerintahan

[18] Menpan.go.id. (2018). Monitoring Dumas Setneg Hadir Rakyat Berterimakasih kepada Presiden. https://www.menpan.go.id/site/berita-

terkini/monitoring-dumas-setneg-hadir-rakyatberterimakasih-kepada-presiden 
256 JIAP | Jurnal IImu Administrasi Publik | Vol. 8, No. 1, Bulan Maret Tahun 2020 hal 237-255 